\title{
YOUTH ENTREPRENEURSHIP AND SMALL AND MEDIUM ENTERPRISES (SMES) GROWTH IN NIGERIA: THE MODERATING ROLE OF INFORMATION AND COMMUNICATION TECHNOLOGY (ICT)
}

\author{
Solomon Adejare BABARINDE \\ Department of Business Administration and Marketing, \\ Redeemer's University, Ede, Osun State, Nigeria \\ Olufemi Samuel OMOYELE \\ Department of Business Administration and Marketing, \\ Redeemer's University, Ede, Osun State, Nigeria \\ Thomas Duro AYODELE \\ Department of Finance, \\ Redeemer's University, Ede, Osun State, Nigeria \\ Adebayo Isaac ADIO \\ Department of Management, \\ University of Nigeria, Enugu Campus, Enugu State, Nigeria
}

\begin{abstract}
The roles that Information and Communication Technology (ICT) play to the growth and development of small and medium scale (SMEs) businesses start-ups in the developed economies cannot be overemphasized, but this is not always the same with what is obtainable in developing countries like Nigeria. This study, for that reason, fills the gap by investigating the relationship between youth entrepreneurship and SMEs growth, taking cognizance of the moderating roles of ICT. The study adopted a cross-sectional research design with a descriptive research method selected to examine the relationship between study variables. Only primary data was used in the study. Primary data was sourced with the questionnaire instrument. The population of the study comprised of 15260 small and medium enterprises in south western Nigeria, as obtained from the office of National Bureau of Statistics (NBS). Slovin's formula was applied to obtain a sample size of 390 from the study population, while youth entrepreneurs were sampled purposively based on age. The findings revealed that ICT has a positive moderating influence on the relationship between
\end{abstract}


Youth Entrepreneurship and Small and Medium Enterprises (SMEs) Growth in Nigeria: The Moderating Role of Information and Communication Technology (ICT)

youth entrepreneurship and SMEs growth. The study recommended among other things that the government should do more in the area of alleviating challenges faced by youths in accessing ICT devices. The Government should also invest more in infrastructure development and promulgate laws that will make network providers deliver excellent services to its subscribers.

Key words: Youth Entrepreneurship, Business Growth, ICT, Small Scale Enterprises.

Cite this Article: Solomon Adejare BABARINDE, Olufemi Samuel OMOYELE, Thomas Duro AYODELE and Adebayo Isaac ADIO, Youth Entrepreneurship and Small and Medium Enterprises (SMEs) Growth in Nigeria: The Moderating Role of Information and Communication Technology (ICT), International Journal of Management, 11(12), 2020, pp. 2516-2526.

http://iaeme.com/Home/issue/IJM?Volume=11\&Issue=12

\section{INTRODUCTION}

The rising reputation of entrepreneurship is the outcome of the global consciousness of increasing competitiveness in the business environment. In Nigeria, the National Institute of Entrepreneurship and Small Business Development emphasises entrepreneurship as a vital element of the strategy to develop Nigeria into a global business hub (Ezeani, 2018). In the past, Nigeria had a temporary sensation of plenty and peace. Nigeria as a result of crude oil and natural resources attracted multinational corporations (MNCs) to the region. This has enabled Nigeria to grow but not at a remarkable rate. Now, Nigeria has awakened to the reality that crude oil and natural resources may not be enough to make the country the giant of Africa. According to Poon \& Hee (1995), the challenge for tomorrow is a more competitive business environment. It has been emphasised in Nigeria that there is a need for graduates and youth generally to develop an entrepreneurial spirit, which is what is most needed in the face of dire unemployment (Ihugba, Odii, \& Njoku, 2013).

Entrepreneurship is the capacity to form and build a vision from virtually nothing. The entrepreneur applies energy to starting and growing an initiative or organisation rather than just inspecting or scrutinizing and is eager to take calculated risks - both individual and financial and then to do everything conceivable to lessen the probabilities of failure (Timmons, 1985). An entrepreneur is a person who has the initiative, drive, energy, and impetus to give a small business the robust thrust it must have to succeed (Robinson, 1966). Recent work has scrutinised the upbringings and practices of entrepreneurs and ownermanagers in Small and Medium Enterprises. The discussion over the difference between an entrepreneur and a small business owner-manager is recognised and ongoing. Economic theories by Knight (1921), Schumpeter (1934) and Kirzner (1973) make a substantial distinction between the strategic decision-making undertakings of an entrepreneur likened with the more monotonous responsibilities performed by a manager. It is contended here that there exists a difference between entrepreneurs, who by feature of their grander decisionmaking capabilities can build firms with the prospective to produce high levels of profit and growth; and other small firm owner-managers and the self-employed who might own capital but do not have similar abilities or potential (Glancey, Greig \& Pettigrew, 1998).

In this study, youth entrepreneurs are studied as owners of small and medium scale businesses because of accelerating economic globalization, advances in science and technology, which continue to revolutionize small and medium scale businesses (Aloulou, 2016). From a business perspective, the shift toward progressively automated business process is intended to result in greater efficiency and effectiveness in small and medium scale business competitiveness (Mitra, Abubakar, \& Sagagi, 2011). Around the world, it is seen that 
nations have incorporated information and communication technology (ICT) into public and private sector business processes (Edoho, 2016). The highlighting of ICT has similarly enhanced Internet diffusion and knowledge rates. The advent of technological novelties opened up SMSB to new opportunities and challenges. It is well-intentioned to mention that information technology has become an imperative element to the business community as it aids and improves business processes. The speedy progression of technology has reinvigorated SMEs to utilize the opportunity to establish, increase, as well as flourish in their businesses (Ikebuaku \& Dinbabo, 2018). All-encompassing participation of SMEs in spawning revenue to different nations such as Singapore have publicized that SMEs' as talented at creating employment opportunities, marshalling local resources, producing a balanced and prosperous society (Federal Government of Nigeria, 2017). SMEs'can play a substantial harmonising role to large sized firms such as oil companies and, in the end, reinforcing the fiscal expansion of Nigeria as a whole.

Youth entrepreneurs are those persons less than 30 years of age that are characteristically inspired to begin an entrepreneurial venture due to a multiplicity of factors, comprising a desire to: be their own boss. The youth Entrepreneur is an initiator, innovator, and risk-bearer who combines tangible and intangible resources in unique ways to produce new products and services. Information and Communication Technologies (ICT) is essential to business startup and growth of Small and Medium Enterprises(SMEs) in developed economies, but this is not always the case for those in developing countries (Akhuemonkhan, Raimi, Patel, \& Fadipe, 2014). Currently, Nigeria is categorized as a developing economy. This study, for that reason, fills the gap by investigating youth entrepreneurship, Small and Medium Enterprises (SMEs) growth: The moderating role of ICT in South-western Nigeria. Hence, this study addressed the following research questions;

- What is the influence of information and communication technology on youth entrepreneurship promotion in Nigeria?

- What are the challenges associated with the usage of information and communication technology by youth entrepreneurs in Nigeria?

\section{LITERATURE REVIEW}

\subsection{Information and Communication Technology}

According to UNESCO (2002), Information and Communication Technologies (ICT) refers to forms of technologies that are used to create, store, share, transmit, or exchange information. Tinio (2003) defines information and communication technologies as an assorted set of technological tools and resources utilized to communicate, and to produce, broadcast, store, and manage information. These technologies include PCs, the Internet, broadcasting technologies (radio and television), and telephony (Tinio, 2003). Tinio also explained that ICT is used to refer to the merging (merging) of audio-visual and telephone networks with computer networks through a single cabling or link system.

Organizational, managerial, and sociological theorists have been intrigued by the potential effects of information technology on the organization ever since its first application in business organizations over 40 years ago. The literature is full of prediction and counterprediction (Taylor \& Williams, 1994; Benjamin \& Levinson, 1993; Delisi, 1990), but most technology change study illustrates a common transformation theme: organizational change effected by new technology, with further information technology radically altering existing organizational structures. Coulson-Thomas (1991), reviewing previous empirical research, indicates that "not one person favoured a continuation of the traditional pyramid form of bureaucratic organization. All are seeking to create organizations that were slimmer, flatter 
and more flexible and adaptable. Zuboff (1989) similarly illustrates that "technology and information can have a corrosive effect on the hierarchical organization of work" (p. 285), while Allen and Scott Morton (1994) contend that "[t]he era into which we are now entering will see qualitative changes wrought by IT. No longer will IT be overlaid onto existing business. It will now be used to restructure the enterprise" (p. 3). Okundaye, Fan \& Dwyer (2019) studied the impact of information and communication technology in Nigerian Small-to Medium-Sized Enterprises.

The focus of the study by Okundaye, Fan \& Dwyer (2019) was on executive-level leaders in small and medium scale business firm who had the official power to support ICT implementation in the studied small and medium Enterprises. The findings from the study by Okundaye, Fan \& Dwyer (2019) contribute to the literature on factors responsible for ICT adoption by management of SME in Nigeria. Several studies exist on ICT and SME's in Nigeria but no previous study to the knowledge of the researcher focused on the extent to which Youth Entrepreneurs in Southwest Nigeria, use information communication technology. This presents study will also provide rich insights into the challenges of using information communication technology by youth entrepreneurs in Southwest Nigeria. Lastly, the study establishes the effect of information communication technology on Youth Entrepreneurship promotion in Southwest Nigeria.

\section{METHODS}

The study adopted a quantitative cross-sectional research design with a descriptive research method selected to examine the relationship between study variables. Primary data was used in the study. Primary data was sourced with the questionnaire instrument. The population of the study comprised 15260 Small and Medium Enterprises (SMEs) in South-Western Nigeria, as obtained from the National Bureau of Statistics (NBC). Slovin's formula was applied to obtain a sample size of 390, while Youth Entrepreneurs were sampled purposively based on age. Descriptive and Inferential statistics were used in the presentation and analysis of data. The descriptive statistics used are percentages and frequency distribution. ANOVA, Linear regression was the inferential statistics used in establishing the relationship between the dependent variable and independent variables as well as testing the hypotheses. ANOVA was adopted for the study because it meets the requirement of relating the variables involved. Model fit for regression to observe the relationship between variable (youth's entrepreneurship) and independent variables (information communication technology: availability, accessibility, and usage):

\section{DATA, RESULTS AND FINDINGS}

\subsection{Demographic Characteristics of Respondents}

All the administered questionnaires were retrieved giving us $100 \%$ return rate. The data in Table 1 show the summary of the demographic characteristics of the respondents that participated in the study. The gender of the respondents shows that more than half of the respondents (54.6\%) were female, while $45.4 \%$ were male. The age of the respondents ranges between 18-30 years. The majority of the respondents, $53.8 \%$, were single, $46.2 \%$, were married. The majority of the respondents $(33.8 \%)$ had elementary education, $19.2 \%$ of them were university graduates, and just only $18.5 \%$ of respondents had no formal education while $12.3 \%$ of them had professional qualifications and $12.3 \%$ postgraduate diploma. As regards the type of enterprise, the highest percentage of the respondents $(42.3 \%)$ is into a cottage industry; agro-allied constituted $30.8 \%$, while $26.9 \%$ of the respondents were into commerce/services. 
The majority of the respondents $(51.5 \%)$ had no family business background, while only $48.5 \%$ had an experience in the family business. However, the study revealed that $34.7 \%$ of the respondents had to be into the industry between $1-4$ years, $27.9 \%$ started the company for less than 1year, while only $5.0 \%$ of respondents had more than ten years of operation. Only $48.5 \%$ of the respondents described their competency in the use of ICT to be below average, $20 \%$ of them said their skill in the use of ICT are average while $19.2 \%$ and $12.3 \%$ are having ability above average and excellent respectively.

Table 1 Socio-Demographic Characteristics of Respondents

\begin{tabular}{|c|c|c|c|}
\hline $\mathbf{S} / \mathbf{N}$ & Socio-demographic Variable & Frequency $(n=390)$ & Percentage(\%) \\
\hline 1 & $\begin{array}{ll}\text { Gender: } & \text { Male } \\
& \text { Female } \\
\text { Total } & \end{array}$ & $\begin{array}{l}177 \\
213 \\
390\end{array}$ & $\begin{array}{l}45.4 \\
54.6 \\
100\end{array}$ \\
\hline 2 & $\begin{array}{l}\text { Age Range (years): } 18-30 \\
\text { Total }\end{array}$ & $\begin{array}{l}390 \\
390\end{array}$ & $\begin{array}{l}100 \\
100\end{array}$ \\
\hline 3 & $\begin{array}{ll}\text { Marital Status: } & \text { Single } \\
& \text { Married } \\
\text { Total } & \\
\end{array}$ & $\begin{array}{l}210 \\
180 \\
390\end{array}$ & $\begin{array}{l}53.8 \\
46.2 \\
100\end{array}$ \\
\hline 4 & $\begin{array}{ll}\text { Qualifications: } & \text { Elementary } \\
& \text { Polytechnic Graduate } \\
& \text { University Graduate } \\
& \text { Professional Studies } \\
& \text { Postgraduate } \\
& \text { No Formal Education } \\
\text { Total } & \end{array}$ & $\begin{array}{c}132 \\
15 \\
75 \\
48 \\
48 \\
72 \\
390\end{array}$ & $\begin{array}{l}33.8 \\
3.8 \\
19.2 \\
12.3 \\
12.3 \\
18.5 \\
100\end{array}$ \\
\hline 5 & $\begin{array}{l}\text { Type of Enterprise: Agro-allied } \\
\text { Commerce and Services } \\
\text { Cottage } \\
\text { Total }\end{array}$ & $\begin{array}{l}120 \\
105 \\
165 \\
390\end{array}$ & $\begin{array}{l}30.8 \\
26.9 \\
42.3 \\
100\end{array}$ \\
\hline 6 & $\begin{array}{l}\text { Competency in the use of ICT: } \\
\text { Below average } \\
\\
\text { Average } \\
\text { Above average } \\
\text { Excellent } \\
\text { Total }\end{array}$ & $\begin{array}{c}189 \\
78 \\
75 \\
48 \\
390\end{array}$ & $\begin{array}{l}48.5 \\
20.0 \\
19.2 \\
12.3 \\
100\end{array}$ \\
\hline
\end{tabular}

Source: Field Survey

\subsection{Information Communication Technology Devices Used by Youth Entrepreneurs}

The result in Table 2 shows the various ICT devices used by youth entrepreneurs and the percentage of youth entrepreneurs using each of the devices in Southwest Nigeria. Some of the respondents had multiple responses. All the respondents $(100 \%)$ claimed to use a radio device. $98.71 \%$ of the respondents use handset, $76.92 \%$ use television, $38.46 \%$ use laptops, $64.10 \%$ have access to internet facility, and $30.77 \%$ use desktop devices. Only $20.51 \%$ claimed to be using an iPad. From the results, all the respondents claimed to use a radio device, and this might be related to its affordability, availability, easy carriage, and up-to-date information dissemination. It may also be because of many handsets coming with a radio application. $98.71 \%$ of the respondents are using a handset. This may be connected to the availability of different GSM network providers in the country and increased network coverage area. The majority of youth entrepreneurs are yet to fully explore the many benefits 
currently been enjoyed in the use of iPad, especially with the ability to get on the sports information during decision-making. This might be related to its cost, fragile in nature, and technicality needed in its usage. It is evident therefore that some youth entrepreneurs still do not use ICT devices and as a result, not taking advantage of the benefit provided by ICT during the entrepreneurial process.

Table 2 Information Communication Technology Devices Used by Youth Entrepreneurs

\begin{tabular}{|l|c|c|}
\hline \multicolumn{1}{|c|}{ Devices } & Number of multiple responses & Percentage of multiple respondents \\
\hline Laptop & 150 & $38.46 \%$ \\
\hline Desktop & 120 & $30.77 \%$ \\
\hline Hand Set & 385 & $98.71 \%$ \\
\hline Internet facility & 250 & $64.10 \%$ \\
\hline Television & 300 & $76.92 \%$ \\
\hline Radio & 390 & $100 \%$ \\
\hline Ipad & 80 & $20.51 \%$ \\
\hline
\end{tabular}

Source: Field Survey

\subsection{Challenges of ICT and Youth Entrepreneurship}

The result in table 4.3 shows that respondents encountered challenges in accessing and using Information and Communication Technology. Using the following proxies to measure challenges, they are the following: inadequate infrastructure, specialized knowledge required for using ICT, high cost of ICT access, non-availability of internet facility, and timeconsuming. As regards the accessibility and use of ICT during the Ideation phase by youth entrepreneurs in the study area, $78.1 \%$ of the respondents affirmed that it led to more cost; $48.6 \%$ reported that the facility was not available. Also, $25.7 \%$ of respondents claimed that it was difficult and required specialized knowledge, while $17.1 \%$ reported that it was timeconsuming and the remaining $6.4 \%$ said inadequate infrastructure. On challenges posed by accessibility and use of ICT during conceptualization phase, majority of the respondents $69.7 \%$ claimed that it was expensive, $(38.4 \%)$ attested that it was not available, $6.5 \%$ confirmed that it required specialized knowledge to use and challenging to learn, $9.2 \%$ indicated that it was time-consuming and only $16.7 \%$ said infrastructure is inadequate. During venture creation phase, the most significant proportion of the respondents $59.2 \%$ reported that it was expensive to access and use ICT, followed by $55.5 \%$ who acclaimed that the facility was not available, only $25.2 \%$ recorded that it required specialized knowledge to use, $14.2 \%$ said it is time-consuming while others $11.7 \%$ attested that infrastructure that supports the use of ICT was not available. For commercialization, the majority of respondents claimed that it was expensive $35.5 \%$, while $23.6 \%$ recorded that the facility was not available, only $2.8 \%$ said it required specialized knowledge to use and $8.1 \%$ said it time consuming and $20.5 \%$ of the respondents said inadequate infrastructure.

The result of the contribution of challenges associated with accessibility and use of ICT to youth entrepreneurship (table 3 a) provides the researcher with a unique way of understanding the contribution of the independent variable to the dependent variable. Table 3 a reveals that challenges of ICT $(\mathrm{t}=14.62, \mathrm{p}<0.05)$ had a positive and significant effect on Youth Entrepreneurship during the ideation phase with a beta value of 0.554 . This implies that the challenges of ICT explained $55.4 \%$ of the variation in youth entrepreneurship during the ideation phase. Also, challenges of ICT $(t=5.021, p>0.05)$ had a positive and significant effect on youth entrepreneurship during the conceptualization phase, with a beta value of 0.325 . This implies that the challenges of ICT explained $32.5 \%$ of the variation in youth entrepreneurship during the conceptualization phase. Also, challenges of ICT $(t=11.260$, 
$\mathrm{p}>0.05$ ) have a positive and significant effect on youth entrepreneurship during commercialization and business growth phase with a beta value of 0.397 . This implies that ICT only explained $39.7 \%$ of the variation in Youth Entrepreneurship during the commercialization phase. This means that challenges associated with accessibility and use of ICT primarily affected youth entrepreneurship during the entrepreneurial process in the study area.

Table 3c \& 3d reveals how much of the variance in the dependents variable (Youth Entrepreneurship) is explained by the model (challenges of information communication technology). Challenges of information communication technology $(F=126.64, p<0.05)$ had a positive and significant effect on youth entrepreneurship with a beta value of 0.575 . This implies that challenges of information communication technology have considerable influence on youth entrepreneurship in southwest Nigeria, and the alternate hypothesis accepted that states that there is meaningful relationship between challenges associated with accessibility and the use of information communication technology and youth entrepreneurship in southwest Nigeria.

Table 3a: Challenges of ICT and Youth Entrepreneurship

\begin{tabular}{|l|c|c|c|c|c|c|c|c|}
\cline { 2 - 9 } \multicolumn{1}{c|}{} & \multicolumn{7}{c|}{ Entrepreneurial Process } \\
\hline Statements & \multicolumn{2}{|c|}{ Ideation Phase } & \multicolumn{2}{c|}{$\begin{array}{c}\text { Conceptualization } \\
\text { Phase }\end{array}$} & \multicolumn{2}{|c|}{$\begin{array}{c}\text { Venture creation } \\
\text { Phase }\end{array}$} & $\begin{array}{l}\text { Commercialization } \\
\text { and business } \\
\text { growth Phase }\end{array}$ \\
\hline $\begin{array}{l}\text { High cost of } \\
\text { accessing ICT }\end{array}$ & 297 & $78.1 \%$ & 230 & $69.7 \%$ & 225 & $59.2 \%$ & 135 & $35.5 \%$ \\
\hline $\begin{array}{l}\text { Non- } \\
\text { availability of } \\
\text { internet } \\
\text { facility }\end{array}$ & 170 & $48.6 \%$ & 111 & $38.4 \%$ & 211 & $55.5 \%$ & 90 & $23.6 \%$ \\
\hline $\begin{array}{l}\text { Required } \\
\text { specialized } \\
\text { knowledge in } \\
\text { ICT }\end{array}$ & 98 & $25.7 \%$ & 25 & $6.5 \%$ & 50 & $25.2 \%$ & 11 & $2.8 \%$ \\
\hline $\begin{array}{l}\text { Time } \\
\text { consumption }\end{array}$ & 65 & $17.1 \%$ & 35 & $9.2 \%$ & 54 & $14.2 \%$ & 31 & $8.1 \%$ \\
\hline $\begin{array}{l}\text { Inadequate } \\
\text { infrastructure }\end{array}$ & 25 & $6.4 \%$ & 65 & $16.7 \%$ & 46 & $11.7 \%$ & 80 & $20.5 \%$ \\
\hline
\end{tabular}

Table 3b:Contribution of Challenges of ICT to Youth Entrepreneurship

\begin{tabular}{|c|l|c|c|c|c|c|}
\hline \multicolumn{2}{|c|}{ Model } & \multicolumn{2}{|c|}{$\begin{array}{c}\text { Unstandardized } \\
\text { Coefficients }\end{array}$} & $\begin{array}{c}\text { Standardized } \\
\text { Coefficients }\end{array}$ & \multirow{2}{*}{ Sig. } & \\
\cline { 3 - 7 } \multicolumn{2}{|c|}{} & B & Std. Error & Beta & & \\
\hline \multirow{3}{*}{1} & (Constant) & 2.460 & .159 & & 15.47 & .000 \\
\cline { 2 - 7 } & Ideation & .554 & .017 & .507 & 14.62 & .000 \\
\cline { 2 - 7 } & Conceptualization & .325 & .025 & .036 & 5.021 & .000 \\
\cline { 2 - 7 } & Venture creation & .495 & .020 & .332 & 9.627 & .000 \\
\cline { 2 - 6 } & $\begin{array}{l}\text { Commercialization and } \\
\text { business growth }\end{array}$ & .397 & .017 & .384 & 11.26 & .000 \\
\hline
\end{tabular}


Youth Entrepreneurship and Small and Medium Enterprises (SMEs) Growth in Nigeria: The Moderating Role of Information and Communication Technology (ICT)

Table 3c: Regression Analysis on Challenges of ICT and Youth Entrepreneurship

\begin{tabular}{|c|c|c|c|}
\hline \multicolumn{4}{|c|}{ Model Summary } \\
\hline $\mathbf{R}$ & $\begin{array}{c}\mathbf{R} \\
\text { Square }\end{array}$ & $\begin{array}{c}\text { Adjusted R } \\
\text { Square }\end{array}$ & $\begin{array}{c}\text { Std. Error of the } \\
\text { Estimate }\end{array}$ \\
\hline $.758^{\mathrm{a}}$ & .575 & .570 & .492 \\
\hline
\end{tabular}

Predictors: (Constant), ICT

Table 3d: ANOVA Result of Regression Analysis of ICT and Youth Entrepreneurship

\begin{tabular}{|c|c|c|c|c|c|c|}
\hline \multicolumn{7}{|c|}{ ANOVA } \\
\hline \multicolumn{2}{|c|}{ Model } & Sum of & Df & Mean & $\mathbf{F}$ & Sig. \\
\hline \multirow[t]{3}{*}{1} & Regression & 122.852 & 4 & 30.713 & 126.648 & $.000^{\mathrm{a}}$ \\
\hline & Residual & 90.940 & 375 & .243 & & \\
\hline & Total & 213.793 & 379 & & & \\
\hline
\end{tabular}

\subsection{Effects of Information Communication Technology on Youth Entrepreneurship}

The result of the contribution of ICT to youth entrepreneurship (table 4a) provides the researcher with a unique way of understanding the contribution of the independent variable to the dependent variable. Table $4 \mathrm{a}$ reveals that ICT $(\mathrm{t}=23.42, \mathrm{p}<0.05)$ had a positive and significant effect on Youth Entrepreneurship during the ideation phase with a beta value of 0.28 . This implies that ICT explained $28 \%$ of the variation in youth entrepreneurship during the ideation phase. Also, ICT $(\mathrm{t}=18.12, \mathrm{p}>0.05)$ had a positive and significant effect on youth entrepreneurship during the conceptualization phase with a beta value of 0.225 . This implies that ICT explained $22.5 \%$ of the variation in youth entrepreneurship during the conceptualization phase. ICT $(\mathrm{t}=24, \mathrm{p}<0.05)$ had a positive and significant effect on youth entrepreneurship during the venture creation phase with a beta value of 0.33 . This implies that ICT explains $33.5 \%$ of the variation in youth entrepreneurship during the venture creation phase. Also, ICT $(\mathrm{t}=0.499, \mathrm{p}>0.05)$ has no definite and significant effect on youth entrepreneurship during commercialization and business growth phase with a beta value of 0.006 . This implies that ICT only explained $0.6 \%$ of the variation in youth entrepreneurship during the commercialization phase. This means that ICT mainly affected youth entrepreneurship during the ideation phase, conceptualization phase, and venture creation phase in the study area.

Multiple generalized regression analysis results (table $4 \mathrm{~b} \& 4 \mathrm{c}$ ) showed the effect of the independent variable on the dependent variable. It reveals how much of the variance in the dependents variable (youth entrepreneurship) is explained by the model (information communication technology). Information communication technology $(\mathrm{f}=47.547, \mathrm{p}<0.05)$ had a positive and significant effect on youth entrepreneurship with a beta value of 0.791 . This implies that information communication technology obtained $79.1 \%$ of the variation in the youth entrepreneurship. Therefore the alternate hypothesis is accepted which states that Information Communication Technology has a significant influence on Youth Entrepreneurship in Southwest Nigeria, and the null hypothesis is rejected which says that Information and Communication Technology has no considerable impact on Youth Entrepreneurship in Nigeria. 
Solomon Adejare BABARINDE, Olufemi Samuel OMOYELE, Thomas Duro AYODELE and Adebayo Isaac ADIO

Table 4a: Contribution of ICT to Youth Entrepreneurship

\begin{tabular}{|c|c|c|c|c|c|c|}
\hline \multirow{2}{*}{\multicolumn{2}{|c|}{ Model }} & \multicolumn{2}{|c|}{$\begin{array}{l}\text { Unstandardized } \\
\text { Coefficients }\end{array}$} & \multirow{2}{*}{$\begin{array}{c}\begin{array}{c}\text { Standardized } \\
\text { Coefficients }\end{array} \\
\text { Beta }\end{array}$} & \multirow[b]{2}{*}{$\mathbf{T}$} & \multirow[b]{2}{*}{ Sig. } \\
\hline & & B & Std. Error & & & \\
\hline \multirow[t]{5}{*}{1} & (Constant) & .493 & .074 & & 6.664 & .000 \\
\hline & Ideation phase & .280 & .012 & .560 & 23.422 & .000 \\
\hline & Conceptualization phase & .225 & .012 & .440 & 18.122 & .000 \\
\hline & Venture creation phase & .332 & .014 & .574 & 24.006 & .000 \\
\hline & $\begin{array}{l}\text { Commercialization and } \\
\text { business growth phase }\end{array}$ & .006 & .012 & .012 & .499 & .618 \\
\hline
\end{tabular}

Table 4b Regression Analysis of ICT and Youth Entrepreneurship

\begin{tabular}{|c|c|c|c|c|}
\hline Model & R & R Square & $\begin{array}{c}\text { Adjusted R } \\
\text { Square }\end{array}$ & $\begin{array}{c}\text { Std. Error of } \\
\text { the Estimate }\end{array}$ \\
\hline 1 & $.889^{\mathrm{a}}$ & .791 & .788 & .346 \\
\hline
\end{tabular}

Predictors: (Constant), ICT

Table 4c ANOVA Result of Regression Analysis on ICT and Youth Entrepreneurship

\begin{tabular}{|c|c|c|c|c|c|c|}
\hline & \multicolumn{6}{|c|}{ ANOVA } \\
\hline & Model & Sum of Squares & Df & Mean Square & $\mathbf{F}$ & Sig. \\
\hline 1 & Regression & 65.149 & 1 & 65.149 & 47.547 & $.000^{\mathrm{a}}$ \\
\hline & Residual & 517.933 & 378 & 1.370 & & \\
\hline & Total & 583.082 & 379 & & & \\
\hline
\end{tabular}

a. Predictors: (Constant), Information and Communication Technology

b. Dependent Variable: Youth entrepreneurship

\section{CONCLUSION}

The study affirms that ICT devices use by youth entrepreneurs are a laptop, desktop, handset, internet facility, television, radio and $\mathrm{iPad}$. As regards the challenges associated with accessibility and use of ICT in the study area, the study revealed that the high cost of accessing ICT, non-availability of internet facility, time-consuming, and inadequate infrastructure are the challenges faced by youth entrepreneurs in the study area. The study determines the extent to which information communication technology affect youth entrepreneurship. The inferential statistical tool was employed using regression analysis to analyze the effect of information communication technology on youth entrepreneurship. The study concluded that ICT devices and challenges had affected youth entrepreneurship Consequently, the study accepts both the alternate hypothesis for the two formulated which were; there is significant relationship between information and communication technology and youth entrepreneurship promotion in Nigeria; and there is a substantial relationship between challenges associated with the accessibility of information communication technology and usage of ICT among youth entrepreneur in southwest Nigeria respectively. On these conclusion premises, the following recommendations are crucial: the increasing popularity of social media and bulk messaging indicates how ICT can stimulate youth during the entrepreneurial process. To fit ICT into the entrepreneurial process of youths, youths entrepreneurs need increased availability and access to the use of ICT devices such as laptops, desktop, handset, internet facility, and Ipad. The government should also do more in the area of alleviating challenges faced by youths in accessing ICT devices. Challenges that should be 
Youth Entrepreneurship and Small and Medium Enterprises (SMEs) Growth in Nigeria: The Moderating Role of Information and Communication Technology (ICT)

assuaged by the Government including but not limited to reducing the high cost of accessing ICT, mitigating the effects of non-availability of internet facility and providing adequate infrastructure to support the use of ICT by the youth entrepreneurs. Furthermore, the Government should also invest more in infrastructure development and promulgate laws that will make network providers deliver excellent services to its subscribers. The study had provided information on the ICT devices used by Youth Entrepreneurs and their effect on youth entrepreneurship. It also shed light on the challenges associated with accessibility and the use of ICT.

\section{FURTHER STUDIES}

Qualitative research in the form of case studies would help develop a richer understanding of the effect of information and communication technology on the promotion of Youth Entrepreneurship in Nigeria. Given the attention placed on information and communication technology and youth entrepreneurship promotion in the current business environment, it would be useful to examine the following;

- Various ways of combating challenges faced by Youth Entrepreneurs in the use of information communication technology

- Another study can also look at information communication technology and youth entrepreneurship in another geographical region of Nigeria. This will better make us know the challenges faced by youth entrepreneurs in the use of ICT outside the Southwestern zone.

\section{REFERENCES}

[1] Akhuemonkhan, I., Raimi, L., Patel, A. \& Fadipe, A. (2014). Harnessing the potentials of technology incubation centres (TICs) as tools for fast-tracking entrepreneurship development and actualisation of the Vision 20:2020 in Nigeria. Humanomics, 30(4), 349-372. https://doi.org/10.1108/H-11-2013-0069

[2] Allen, J. \& Scott, M. (1994). Information Technology and the Corporation of the 1990s: Research Studies. Oxford: Oxford University Press.

[3] Aloulou, W. (2016). Predicting entrepreneurial intentions of freshmen students from EAO modelling and personal background: a Saudi perspective. Journal of Entrepreneurship in Emerging Economies, 8(2), 180-203.

[4] Benjamin, I. \& Levinson, E. (1993). A Framework for Managing IT-Enabled Change. Sloan Management Review. 34(4), 23-33.

[5] DeLisi, P. (1990). Lessons from the steel axe: culture, technology and organizational change. London: Routledge and Kegan Paul.

[6] Edoho, F. (2016). Entrepreneurship paradigm in the new millennium: A critique of public policy on entrepreneurship. Journal of Entrepreneurship in Emerging Economies, 8(2), 279294. https://doi.org/10.1108/JEEE-08-2015-0043

[7] Ezeani, E. (2018). Barriers to graduate employment and entrepreneurship in Nigeria. Journal of Entrepreneurship in Emerging Economies, 10(3), 428-446. https://doi.org/10.1108/JEEE02-2017-0009

[8] Federal Government of Nigeria (2017). Key statistics - labour market, unemployment. National Bureau of Statistics, available at: www.nigerianstat.gov.ng/ (accessed 26 September 2019) 
[9] Glancey, K., Greig, M., \& Pettigrew, M. (1998). Entrepreneurial dynamics in small business service firms. International Journal of Entrepreneurial Behaviour \& Research, 4(3), 249-268. doi:10.1108/13552559810235547

[10] Ihugba, O., Odii, A. \& Njoku, A. (2013). Challenges and prospects of entrepreneurship in Nigeria. Academic Journal of Interdisciplinary Studies, 2(5), 25-36

[11] Ikebuaku, K. \& Dinbabo, M. (2018). Beyond entrepreneurship education: business incubation and entrepreneurial capabilities. Journal of Entrepreneurship in Emerging Economies, 10(1), 154-174. https://doi.org/10.1108/JEEE-03-2017-0022

[12] Mitra, J., Abubakar, Y. \& Sagagi, M. (2011). Knowledge creation and human capital for development: the role of graduate entrepreneurship. Education + Training, 53(5), 462-479. https://doi.org/10.1108/00400911111147758

[13] Okundaye, K., Fan, S. \& Dwyer, R. (2019). Impact of information and communication technology in Nigerian small-to medium-sized enterprises. Journal of Economics, Finance and Administrative Science, 24(47), 29-46. https://doi.org/10.1108/JEFAS-08-2018-0086

[14] Poon, J., \& Hee T. (1995). Enhancing Entrepreneurial Spirit: A Resolve for University Graduates. Management Research News, 18(1/2), 31-52. doi:10.1108/eb028398

[15] Robinson, R.(1966). Financing the Dynamic Small Firm. New York: Wadsworth.

[16] Taylor, J. \& Williams, H. (1994). Themes and issues in information polity. Journal of Information technology 5(3)

[17] Tinio, V. (2003). ICT in Education. UNDP-APDIP UNESCO (2002). Information Communication Technology in Education. A curriculum for Schools and Programme of Teacher development. France: UNESCO.

[18] Timmons, A. (1985). New Venture Creation. Homewood: Irwin.

[19] Zuboff, S. (1988). In the Age of the Smart Machine. The future of Work and Power. New York: Basic Books. 